\title{
CZĘTOŚĆ SPOŻYWANIA ALKOHOLU I ZAŻYWANIA NARKOTYKÓW PRZEZ GIMNAZJALISTÓW SZKÓŁ OŚWIĘCIMSKICH
}

\section{DRINKING AND DRUG ABUSE AMONG GYMNASIUM STUDENTS OŚWIĘCIM}

\author{
Dariusz Góra \\ Wydział Nauk o Ziemi, Uniwersytet Śląski \\ DOI: https://doi.org/10.20883/ppnoz.2019.58
}

\section{STRESZCZENIE}

Wstęp. Uzależnienia chemiczne (alkohol, nikotyna, substancje psychoaktywne) jest jednym z największych problemów społecznych współczesnego świata. Pomimo szeroko zakrojonych programów profilaktycznych uzależnienia nadal pozostają kluczową bolączką obecnych społeczeństw. W obliczu obniżającego się progu inicjacji substancji uzależniających grupa szczególnie zagrożona tym problemem jest obecnie młodzież. Alkohol i narkotyki to częsta przyczyna uzależnień wśród dzieci i młodzieży. Trudno znaleźć skuteczne metody zapobiegania zachowaniom ryzykownym wśród tej grupy osób. Przy obecnie nasilonych niekorzystnych zjawiskach, takich jak bezrobocie, trudna sytuacja rodzin, stres, depresje czy upadek moralny, trudno jest zachować komfort psychiczny i zdrowie osobie dorosłej, a tym bardziej dziecku. Różnego rodzaju napięcia i konflikty młodzież coraz częściej próbuje rozładować, sięgając po alkohol i narkotyki.

Cel pracy. Celem artykułu jest próba przedstawienia częstości i przyczyn spożywania alkoholu oraz zażywania narkotyków przez gimnazjalistów szkół oświęcimskich.

Materiał i metody. Materiałem badawczym była anonimowa ankieta (skierowana do uczniów klas III szkół gimnazjalnych) zawierająca pytania dotyczące częstości i przyczyn picia alkoholu oraz zażywania narkotyków. Do badań wykorzystano kwestionariusz ankiety, który został wypełniony przez 408 gimnazjalistów. Wyniki poddano analizie statystycznej.

Wyniki. Codziennie alkohol spożywa 3\% chłopców i 4\% dziewcząt, najczęściej jest to piwo. Najwięcej adolescentów sięga po alkohol i narkotyki, by zaimponować grupie rówieśniczej lub z powodu problemów w nauce i problemów osobistych.

Wnioski. Małe zainteresowanie ze strony rodziców w sprawach ważnych dla młodziė̇y, niewystarczająca bliskość z rodziną oraz wychowywanie się w rodzinach niepełnych są czynnikami wpływającymi na częstość picia alkoholu i palenia papierosów wśród młodzieży. Sposobem na zapobieganie problemom związanym z zażywaniem alkoholu i narkotyków przez młodych ludzi jest wprowadzenie kontroli ich spożycia, zniesienie reklamy i marketingu tych produktów, a także budowa prawidłowych wzorców osobowych dla młodzieży.

Słowa kluczowe: tytoń, zachowania zdrowotne, alkohol, młodzież, narkotyki.

\section{ABSTRACT}

Introduction. Chemical addictions (alcohol, nicotine, psychoactive substances) is one of the biggest social problems in the modern world. Despite extensive programs of preventive addiction, they remain a key problem of contemporary societies. In the face of the decreasing threshold of addictive substance initiation, the group particularly at risk is currently young people. At present, it is difficult to find effective methods to prevent risky behavior among this group of people. With the currently unfavorable phenomena, such as unemployment, the difficult situation of families, stress, depression and moral collapse, it is difficult to maintain the mental comfort and health of an adult, and even more so for a child.

Aim of the study. The purpose of the article is to try to show the frequency and causes of alcohol consumption and drug use by junior high school students from Oświęcim.

Material and methods. The research material was an anonymous questionnaire (addressed to third grade school students) containing questions about the frequency and causes of alcohol consumption and drug use. A questionnaire was used for the research, which was completed by 408 junior high school students. The results were subjected to statistical analysis.

Results. Every day, alcohol consumes $3 \%$ of boys and $4 \%$ of girls, most often it is beer. Most adolescents use alcohol and drugs to impress their peer group because of their academic and personal problems.

Conclusions. Little interest on the part of parents on issues important for young people, insufficient closeness with family and upbringing in incomplete families are factors influencing the frequency of drinking alcohol and smoking among young people. The way to prevent problems related to the use of alcohol and drugs by young people is to control their consumption, abolish the advertising and marketing of these products, as well as to build proper personal patterns for young people.

Keywords: tobacco, health behaviors, alcohol, youth, drugs.

\section{Wstęp}

W dużym stopniu zdrowie każdego człowieka jest determinowane przez jego styl życia. Wiele zaburzeń, które występują u dzieci i młodzieży, ma podłoże behawioralne.
To, co młody człowiek wniesie w swoje dorosłe życie, jest niezwykle ważne dla niego samego i następnych pokoleń. Zdrowie w okresie młodzieńczym, wg WHO, to dobrostan imożliwość pełnego wykorzystania potencjału rozwojowe- 
go w wymiarach: somatycznym, psychicznym, społecznym i duchowym [1]. Uzależnienie chemiczne (alkohol, nikotyna, substancje psychoaktywne) jest jednym z największych problemów społecznych współczesnego świata. Pomimo szeroko zakrojonych programów profilaktycznych uzależnienia nadal pozostają kluczową bolączką współczesnych społeczeństw. W obliczu obniżającego się progu inicjacji alkoholowej czy narkotycznej grupą szczególnie zagrożoną tym problemem jest obecnie młodzież. Alkohol i narkotyki to częsta przyczyna uzależnień wśród dzieci i młodzieży. Obecnie trudno znaleźć skuteczne metody zapobiegania zachowaniom ryzykownym wśród tej grupy osób. Przy nasilonych niekorzystnych zjawiskach, takich jak bezrobocie, trudna sytuacja rodzin, stres, depresje czy upadek moralny, trudno zachować komfort psychiczny i zdrowie osobie dorosłej, a tym bardziej dziecku. Różnego rodzaju napięcia i konflikty młodzież coraz częściej próbuje rozładować, sięgając po alkohol i narkotyki [2, 3].

\section{Cel}

Celem artykułu jest próba przedstawienia częstości i przyczyn spożywania alkoholu oraz zażywania narkotyków przez gimnazjalistów szkół oświęcimskich

\section{Materiał i metody}

Materiał badawczy został zebrany w marcu 2018 r. Do pracy użyto autorskiego kwestionariusza pod tytułem „Moje zdrowie - dbam o nie". Anonimowa ankieta zawierała kilka pytań dotyczących częstości spożywania alkoholu i narkotyków oraz ich przyczyny, a także relacji z rodzicami. Na podstawie procentowych obliczeń (z podziałem na płeć) ustalono zależności pomiędzy badanymi zjawiskami i dokonano ich interpretacji. Ankieta była skierowana do uczniów klas III Gimnazjum (408 uczniów, w tym 205 chłopców i 203 dziewcząt). W niniejszym artykule uwzględniono i opracowano następujące kwestie:

1. Podaj częstotliwość spożywania przez Ciebie alkoholu w ostatnim półroczu.

2. Wymień rodzaj alkoholu spożywanego przez Ciebie (uczniowie mogli wybrać kilka odpowiedzi).

3. Wymień przyczyny spożywania alkoholu przez Ciebie (uczniowie mogli wybrać kilka odpowiedzi).

4. Podaj częstotliwość zażywania przez Ciebie narkotyków w ostatnim półroczu.

5. Wymień przyczyny zażywania narkotyków przez Ciebie (uczniowie mogli wybrać kilka odpowiedzi).

6. Jakie są Twoje relacje $\mathrm{z}$ rodzicami?

\section{Wyniki}

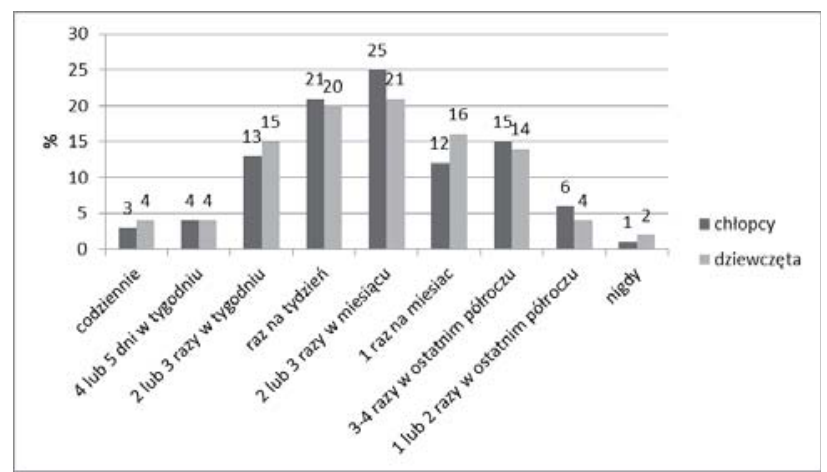

Rycina 1. Częstość picia alkoholu przez młodzież w ostatnim półroczu (opracowano na podstawie zebranych danych)

25\% ankietowanych chłopców i 21\% dziewcząt pije alkohol 2-3 razy w miesiącu. Raz na tydzień spożywa 21\% chłopców i 20\% dziewcząt. Codziennie 3\% chłopców i 4\% dziewcząt sięga po alkohol. Trzy lub cztery razy w ostatnim półroczu 15\% chłopców i 14\% dziewcząt piło alkohol. Nigdy alkoholu nie piło 1\% chłopców i 2\% dziewcząt (Rycina 1).

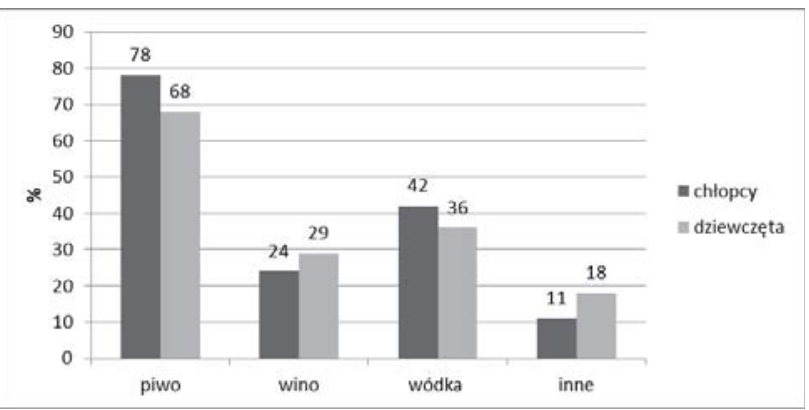

Rycina 2. Rodzaj spożywanego alkoholu przez młodzież w ostatnim półroczu (opracowano na podstawie zebranych danych)

Wśród ankietowanych chłopców $78 \%$ pije piwo, wśród dziewczą - $68 \%$. Picie wódki deklaruje $42 \%$ chłopców i 36\% dziewcząt. Wino spożywa 24\% chłopców i 29\% dziewcząt. Inne napoje alkoholowe pije 11\% chłopców i 18\% dziewcząt (Rycina 2).

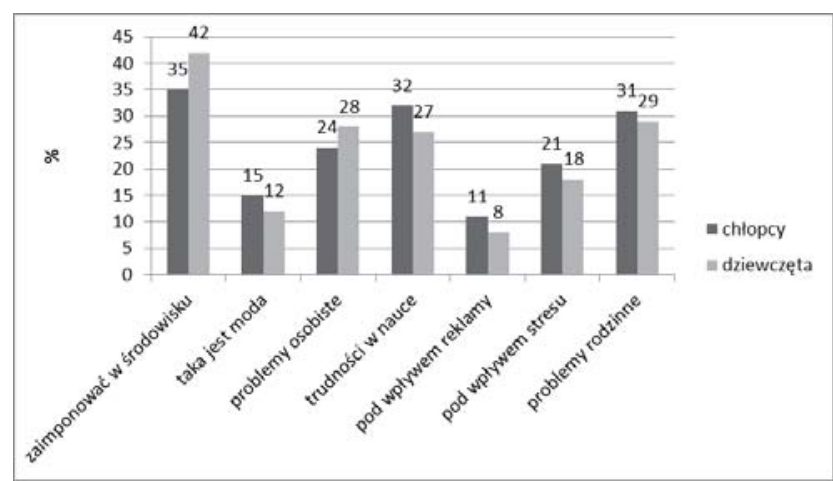

Rycina 3. Przyczyny spożywania alkoholu przez młodzież w ostatnim półroczu (opracowano na podstawie zebranych danych) 
Aż 42\% dziewcząt i 35\% chłopców przyznaje się, że spożywa alkohol, aby zaimponować środowisku. 32\% ankietowanych chłopców i 27\% dziewcząt spożywa alkohol, ponieważ mają trudności w nauce. Z powodu problemów rodzinnych po alkohol sięga 31\% chłopców i 29\% dziewcząt. Natomiast problemy osobiste stanowią przyczynę zażywania alkoholu u 24\% chłopców i $28 \%$ dziewcząt (Rycina 3).

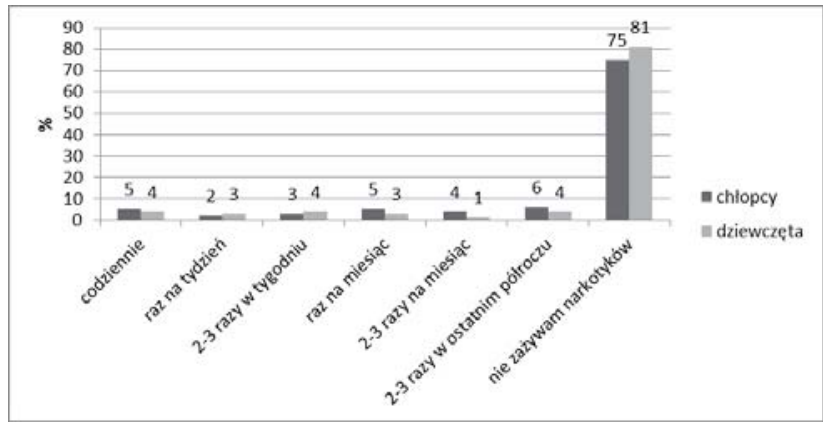

Rycina 4. Częstotliwość zażywania narkotyków przez młodzież w ostatnim półroczu (opracowano na podstawie zebranych danych)

81\% dziewcząt i 75\% chłopców nie zażywa narkotyków. Dwa lub trzy razy w ostatnim półroczu $6 \%$ ankietowanych chłopców i 4\% dziewcząt zażywało narkotyki. Aż

$2725 \%$ chłopców i 4\% dziewcząt codziennie sięga po narkotyki, a raz na tydzień 2\% chłopców i 3\% dziewcząt (Rycina 4).

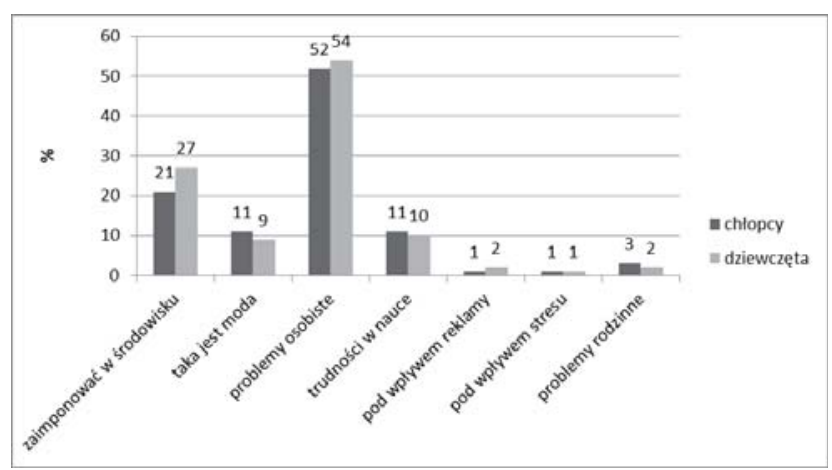

Rycina 5. Przyczyny zażywania narkotyków przez młodzież w ostatnim półroczu (opracowano na podstawie zebranych danych)

Z powodów osobistych $54 \%$ dziewcząt i 52\% chłopców sięga po narkotyki. 27\% dziewcząt i 21\% chłopców zażywa narkotyki, by zaimponować swojemu środowisku. Pod wpływem mody 11\% chłopców i 9\% dziewcząt sięga po narkotyki (Rycina 5).

Dziewczęta przyznały, że tata (28\%) i mama (31\%) a chłopcy, że tata (23\%) i mama (11\%) są ich przyjaciółmi. Według ankietowanych (bez względu na płeć) 10\% przyznaje, że rodzice się nie interesują swoim dzieckiem (Rycina 6).

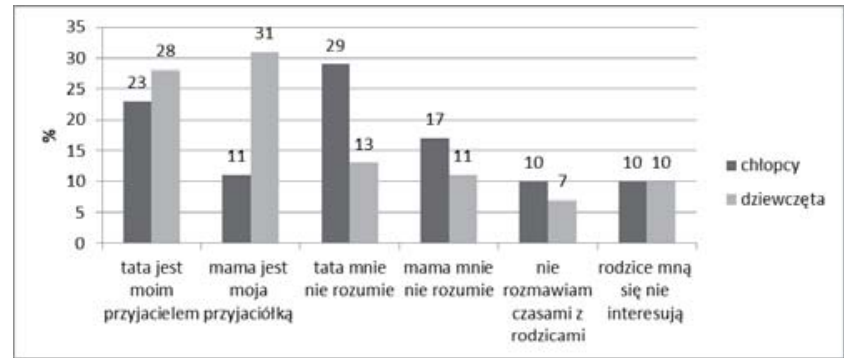

Rycina 6. Relacje panujące w domu rodzinnym uczniów (opracowano na podstawie zebranych danych)

\section{Dyskusja}

Młodzież w Unii Europejskiej w wieku 12-16 lat ma za sobą inicjację alkoholową. Średnio jednorazowo młoda osoba wypija ponad $60 \mathrm{~g}$ czystego alkoholu, co stanowi równowartość prawie 2 I piwa. Przeciętny wiek inicjacji alkoholowej w Polsce wynosi 11,9 lat wśród chłopców, a u dziewcząt 14,2 lat. Przynajmniej raz po napoje alkoholowe sięgało ponad $87 \%$ gimnazjalistów z klas trzecich i ponad 95\% uczniów drugich klas szkół ponadgimnazjalnych. Co czwarty zgon młodego mieszkańca Europy Zachodniej w wieku 15-29 lat jest związany z piciem alkoholu, a w Europie Wschodniej alkohol jest sprawcą co trzeciego zgonu wśród młodzieży. Alkoholizm wieku średniego ma swój początek we wczesnej dorosłości lub nawet w okresie adolescencji. Młodzież spożywając alkohol w coraz młodszym wieku uzależnia się 3-4 krotnie szybciej niż dorośli. Intensywne picie alkoholu przed 20. rokiem życia prowadzi do uzależnienia nawet w ciągu kilku miesięcy. Im młodsze nastolatki piją alkohol, tym częściej wykazują inne zachowania ryzykowne: sięganie po narkotyki, uprawianie seksu z wieloma partnerami. Zazwyczaj też słabsze wyniki w nauce [1].

Picie alkoholu przez niepełnoletnich może doprowadzić do trwałych uszkodzeń funkcji mózgu, szczególnie w odniesieniu do pamięci, zdolności motorycznych i koordynacji. Dziecko, które zażywa narkotyki i pije alkohol, ma obniżoną sprawność intelektualną, mniejszą zdolność koncentracji oraz zapamiętywania, łatwiej się męczy, jest zachwianie emocjonalne (od euforii do całkowitej apatii) i występuje u niego większa drażliwość i nadpobudliwość [4].

Społeczna aprobata spożywania alkoholu i zażywania narkotyków przez młodzież i łatwa dostępność środków odurzających stwarzają największe zagrożenie we współczesnym świecie. Powszechność to przede wszystkim łatwa dostępność i przeświadczenie, że narkotyki i alkohol są bardzo powszechne w miejscach, gdzie młodzież chętnie spędza swój wolny czas, na koncertach czy też w dyskotekach [1].

Innym, nie mniej istotnym czynnikiem, a może w rozwoju dzieci i młodzieży jeszcze ważniejszym, jest picie al- 
koholu i zażywanie narkotyków przez rówieśników, którzy uważają, że bez odurzenia nie ma dobrej zabawy. W badanej grupie gimnazjalistów 21\% chłopców i 20\% dziewcząt raz na tydzień spożywa alkohol (Rycina 1). Prawdopodobnie spożywa go też $w$ czasie zabaw z rówieśnikami.

W wieku dorastania presja środowiska ma ogromny wpływ na kształtowanie się zachowań młodego człowieka, a alkohol i narkotyki, jako "coś" zakazanego, nabierają szczególnej wartości. Nacisk rówieśników może mieć charakter bezpośredni (namawianie) lub pośredni (modelowanie postrzeganych norm społecznych). Rówieśnicy odgrywają ogromną rolę. Lansowany jest wzór człowieka silnego, nieprzejmującego się problemami i takiego, który powinien pasować do grupy. Zażywanie narkotyków i spożywanie dużej ilości alkoholu jest akceptowane przez część młodzieży jako model życia i wzór do naśladowania [5]. Z przeprowadzonych badań wynika, że po narkotyki sięga 21\% chłopców i 27\% dziewcząt, a alkohol spożywa 35\% chłopców i 42\% dziewcząt po to, aby zaimponować rówieśnikom (Ryciny 3, 5). Potrzeba poczucia przynależności do grupy rówieśniczej, poczucia bycia "dorosłym" są dla młodego człowieka tak ważne, że gotów jest zdobyć je za wszelka cenę. Nawet za cenę złamania normy, którą zwykle akceptuje. Młodzi ludzie gotowi są niemal na wszystko, by nie zostać "odmieńcami". Nastolatek osiąga ten cel poprzez obserwację zachowań ludzi dorosłych oraz zachęcających informacji głównie z filmów. Zdarza się, że dorośli z najbliższego otoczenia dostarczają negatywnych wzorców. W filmach alkohol i narkotyki kojarzone są z przygodą i byciem dorosłym. Te czynniki powodują, że nastolatek kształtuje sobie pozytywny obraz alkoholu i narkotyków, a w konsekwencji sięga po nie, by przyspieszyć nadejście własnej dorosłości [6].

Zaburzone więzi emocjonalne między członkami rodziny przyczyniają się do dezintegracji tej wspólnoty, dysfunkcji emocjonalno-społecznej, konfliktów między rodzicami oraz rodzicami i dziećmi, atomizacji członków rodziny i osamotnienia dzieci w środowisku rodzinnym [5].

Z przeprowadzonych badań wynika, że ani ojcowie nie rozumieją swoich synów (29\%) i córek (19\%), ani matki nie rozumieją swoich synów (17\%) i córek (11\%). Poza tym, zarówno chłopcy, jak i dziewczęta uważają, że 10\% ojców i matek nie interesują się nimi (Rycina 6).

Najważniejszym zadaniem w zakresie prawidłowego rozwoju procesów psychicznych jest zaspokojenie dziecku potrzeby kontaktu społecznego wyrażającego się w poczuciu więzi emocjonalnej. Poczucie więzi emocjonalnej uzyskuje dziecko przede wszystkim przez bliskie współżycie z rodzicami i rodzeństwem. Więź emocjonalna rodzi się $\mathrm{w}$ oparciu o dobrą atmosferę domu rodzinnego i mi- łość okazywaną dziecku przez najbliższych. Życie rodzinne jest pierwszym środowiskiem społeczno-emocjonalnym, w którym dziecko uczy się przeżyć psychicznych, reakcji na bodźce, na uczucia, uczy się także odczytywać i wyrażać nadzieje i obawy oraz możliwy wybór reakcji na uczucia przejawiane przez innych. Badania wykazują, iż sposób, w jaki rodzice traktują dzieci i czy poświęcają im należyty czas, ma głęboki i trwały wpływ na życie emocjonalne dziecka [7]. Poczucie więzi z rodziną pomaga w osiągnięciu dojrzałości emocjonalnej, rozumianej jako świadome kierowanie swoim zachowaniem i posiadaniem umiejętności przystosowania się do środowiska społecznego [8]. Dlatego też życzliwa rodzinna atmosfera, prawidłowy model wychowania w życiu rodzinnym, właściwe stosunki uczuciowe między rodzicami i dziećmi oraz między rodzeństwem są podstawowymi paradygmatami prawidłowego rozwoju psychicznego dziecka i właściwego przygotowania do życia społecznego w grupach ludzkich. Dla rozwoju i podtrzymania więzi w rodzinie bardzo ważna jest miłość małżeńska i rodzinna, atmosfera życia domowego, zaspokojenie potrzeb psychicznych i społecznych w środowisku rodzinnym, wypełnianie funkcji rodzicielskich i postaw rodzicielskich [9].

Dzieci mające zaburzone stosunki uczuciowe z rodzicami: emocjonalnie odrzucane przez rodziców, wykazują często postawę lękową i wrogość oraz są bardzo podatne na wpływ swoich rówieśników. Sytuacja ta sprzyja ich nieprawidłowej socjalizacji i niewłaściwemu ukształtowaniu się osobowości. Stałe poczucie zagrożenia, lęk i wrogość powodują silne napięcia emocjonalne, na które dziecko reaguje agresją lub biernością, a nawet apatią. Sposób reakcji na odrzucenie emocjonalne przez rodziców zależy między innymi od struktury stosunków w rodzinie, od stylu wychowania, wzorów i wartości, jakie rodzina przekazuje dziecku, postaw rodzicielskich, a także właściwości cech osobowych dziecka $[9,10]$.

Niezaspokojona potrzeba uczuć emocjonalnych wywołuje u dzieci najrozmaitsze urazy psychiczne, powodujące poczucie osamotnienia, które przyczynia się do poczucia własnej niższości i niepełnej wartości. Dzieciom tym nie zależy na osiągnięciu dobrych wyników w nauce, są bierne i niechętne, wykazują mało inicjatywy, a nawet przejawiają apatyczne zachowania. Mają znaczne trudności w koncentrowaniu uwagi na wykonywanym zadaniu, uwaga ich jest rozproszona i mało stabilna, są nadpobudliwe ruchowo. W zachowaniu ich często trudno jest uchwycić istnienie racjonalnych motywów postępowania. Wydaje się, że o postępowaniu ich decydują jedynie przypadki i chwilowe emocje. Takie postępowanie wskazuje na zaburzenia emocjonalno-motywacyjnej sfery osobowości. 
Przejawiają się one przede wszystkim w nieprawidłowym nawiązywaniu kontaktów społecznych i najczęściej przyjmują formy krańcowe: od emocjonalnego „przyklejenia się" do każdej dorosłej osoby do oziębłości uczuciowej w stosunku do drugiego człowieka, a także dążenie do izolacji. Zaburzenie więzi emocjonalnej między rodzicami a dzieckiem może przybierać różne postacie. Należą do niech między innymi rozluźnienie więzi emocjonalnej w rodzinie między jej członkami, obojętność emocjonalna rodziców wobec dziecka, wreszcie zanik więzi emocjonalnej przechodzący w negatywne układy emocjonalne. Brak pozytywnych uczuć rodziców wobec dziecka cechuje wzajemny chłód emocjonalny, brak emocjonalnego zainteresowania problemami dziecka. Rodzice w takich przypadkach, choć mogą starać się o stworzenie pozorów dbatości o dziecko, skutecznie izolują je od siebie [1, 11].

Dlatego istnieje potrzeba systematycznego opracowywania i doskonalenia skutecznych programów przeciwdziałających rozpowszechnianiu spożywania alkoholu przez nieletnich i zażywaniu narkotyków, a także programów zachęcających dzieci i młodzież do prozdrowotnego stylu życia.

\section{Wnioski}

Picie alkoholu i zażywanie narkotyków przez młodzież gimnazjalną jest problemem złożonym, który można nazwać egzystencjalnym. Kryzys koreluje negatywnie z rozpoczęciem i kontynuowaniem picia alkoholu oraz zażywania narkotyków przez młodzież, a im wcześniejsza jest inicjacja zażywania tych środków, tym konsekwencje i problemy w późniejszym wieku są większe. Nadużywanie alkoholu i zażywanie narkotyków przez młodzież bardzo często prowadzi do ciężkich zatruć. Ze względu na niską tolerancję tych substancji przez mózg u młodego człowieka ulega szybszemu uszkodzeniu niż u dorosłych.

Więzi emocjonalne funkcjonujące $w$ rodzinie warunkują atmosferę życia domowego, wzajemne wsparcie się w trudnych sytuacjach wyzwalają pozytywne postawy rodzicielskie.

Należy więc uznać, że podstawowym czynnikiem w procesie kształtowania osobowości dziecka jest więź rodzinna. Pozytywne kontakty uczuciowe w rodzinie mają olbrzymi wpływ na socjalizację, wychowanie, opiekę i rozwój sfery emocjonalnej u dzieci. Jeśli rodzice poświęcają czas dziecku i zapewniają mu poczucie bezpieczeństwa, akceptacji, miłości, życzliwości i jeśli okażą mu przywiąza- nie uczuciowe, stworzą wówczas podstawy do rozwoju osobowości zrównoważonej i społecznie dobrze przystosowanej.

\section{Oświadczenia}

Oświadczenie dotyczące konfliktu interesów

Autorzy deklarują brak konfliktu interesów.

Autorzy deklarują brak źródeł finansowania.

\section{Piśmiennictwo}

1. Nazarko KE, Bielska DE. Picie alkoholu - częste zachowanie ryzykowne młodzieży szkół ponadgimnazjalnych. Prz Lek. 2012; 69(10): 878-883.

2. Domaradzka M, Jachimowicz-Gaweł D. Uzależnienia chemiczne (alkohol, nikotyna, substancje psychoaktywne) w opiniach i doświadczeniach młodzieży gimnazjalnej powiatu chełmińskiego. Probl Hig Epidemiol. 2014; 95(2): 412-418.

3. Paavola M, Vartiainen E, Haukkala A. Smoking, alcohol use and physical activity: A 13-year longitudinal study ranging from adolescence into adulthood. Journal Adol Health. 2004; 35: 238-244

4. Roberts C, Currie C, Samdal O. Measuring the health and health behaviorus of adolescents through cross-national survey research: recent developments in the Health Behaviour in School-aged Children (HBSC) study. J Publ Health. 2007; 15: 179.

5. Skoczylas P, Żebrowski M. Ocena stopnia zagrożenia alkoholizmem wśród dzieci i młodzieży ze środowisk wielkomiejskich dotkniętych patologiami społecznymi. Probl Hig Epidemiol. 2009; 90: 271.

6. Pisarska A. Właściwości środowiska sąsiedzkiego jako czynnik chroniący/ryzyka używania przez młodzież substancji psychoaktywnych. Przegląd badań. Alkoh Narkom. 2009; 22: 29.

7. Goleman D. Inteligencja emocjonalna. Poznań 2007.

8. Czeredrecka B. Potrzeby psychiczne sierot społecznych. Warszawa 1988.

9. Cudak H. Osamotnienie dzieci we własnej rodzinie. Encyklopedia pedagogiczna XXI wieku. Warszawa 2004.

10. Trindade, Correia R. Adolescentes et alcool. Estudo do comportamento de consume de alcool na adolescencia (Adolescents and alcohol. Study of alcohol consumption behavior in adolescence). Anal Psicol. 1999; 17: 591.

11. Ponczek D, Olszowy I. Styl życia młodzieży i jego wpływ na zdrowie. Probl Hig Epidemiol. 2012; 93(2): 260-268.

Adres do korespondencji:

Dariusz Góra

Uniwersytet Śląski

Wydział Nauk o Ziemi

ul. Będzińska 60

41-200 Sosnowiec 